\title{
The Girl with the Brown Crayon
}

This book has been awarded Harvard University Press's annual prize for an outstanding publication about education and society, established in 1995 by the Virginia and Warren Stone Fund. 


\section{By the same author}

White Teacher

Wally's Stories

Boys and Girls: Superheroes in the Doll Corner

Mollie Is Three: Growing Up in School

Bad Guys Don't Have Birthdays: Fantasy Play at Four

The Boy Who Would Be a Helicopter

You Can't Say You Can't Play

Kwanzaa and $\mathrm{Me}$ 


\section{Vivian Gussin Paley}

The Girl

with the

Brown Crayon

Harvard University Press

Cambridge, Massachusetts

London, England 
Copyright $\odot 1997$ by the President and Fellows of Harvard College All rights reserved

Printed in the United States of America

Fourth printing, 2001

Cover illustration taken from Frederick by Leo Lionni. Copyright $\odot 1967$ and renewed 1995 by Leo Lionni. Reprinted by permission of Random House, Inc.

\section{Library of Congress Cataloging-in-Publication Data}

Paley, Vivian Gussin, 1929-

The girl with the brown crayon / Vivian Gussin Paley.

$$
\text { p. } \mathrm{cm} \text {. }
$$

ISBN 0-674-35439-7 (cloth)

ISBN 0-674-35442-7 (pbk)

1. Language arts (Preschool)-Illinois-Chicago-Case studies.

2. Children's literature-Study and teaching (Preschool)-Illinois-

Chicago-Case studies. 3. Preschool children-Illinois-

Chicago-Books and reading-Case studies.
4. Lionni, Leo, 1910
I. Title
LB1 140.5.L3P35 1997
$372.6-\mathrm{dc} 20 \quad 96-34708$

Designed by Gwen Frankfeldt 
To Irving 
